\title{
A Study of Solid Waste Generation in Residential College UNIMAS West Campus as Potential Renewable Energy
}

\author{
Mohd Azrin Mohd Said ${ }^{1}$, and Bush Engat Ritchie ${ }^{2}$ \\ ${ }^{1,2}$ Department of Mechanical and Manufacturing Engineering, Faculty of Engineering, \\ Universiti Malaysia Sarawak, 94300 Kota Samarahan, Sarawak, Malaysia. \\ ${ }^{1}$ Email: msmazrin@feng.unimas.my,2Email: bushritchie@gmail.com
}

\begin{abstract}
Solid waste management has become a critical issue faced by Malaysia due to the country's rapid development, both in population and economic. The same goes to the tertiary education institutions, which also faced by Universiti Malaysia Sarawak, (UNIMAS). UNIMAS is a hostel provided campus, where the human traffic is considerably high. Everyday large amount of solid waste are produced by the residents of UNIMAS. Statistic data and percentage of solid waste produced by UNIMAS residents according to type have never been investigated. Therefore this study provides an insight of this kind of data for the purpose of future development in UNIMAS solid waste management. The type of solid waste produced by Residential College UNIMAS West Campus and its percentages and volume produced are discussed focusing on the solid waste that have potential energy value and recyclable materials. The data in terms of percentage and approximate amount of volume was applied in the calculation of the potential energy of the solid waste recovery according to the types. The result shows that the total potential amount of energy from solid waste produced by Residential College UNIMAS West campus could reach up to $14027.19 \mathrm{~kJ} / \mathrm{kg}$ where the highest value that is $22.64 \%$ of energy content was contributed by Tun Ahmad Zaidi College.
\end{abstract}

Keywords: Solid Waste, Energy, Renewable Energy, Residential College, UNIMAS

\section{Introduction}

Rapid economic development, growth in population, change in life style, inadequate infrastructure and expertise, and land scarcity make the management of solid waste become one of Malaysia's most critical environmental issues. Production of waste through the consumer products is the highest. Due to development, our education system has been improved followed by an increasing in the growth population in campus as well. In Universiti Malaysia Sarawak (UNIMAS) itself the student intake for the year 2012 reaches 4,939 people, among the highest student intake in Malaysia. UNIMAS currently has some 12,000 students while its full capacity is 20,000 [1]. Solid waste is one of the largest amounts of waste produced in campus where the current method of disposal is managed by Trienekens Sdn Bhd in which the final step is either landfilling or incineration.

Solid wastes are classified on the basis of source of generation and type. The source of solid wastes has been consistent, dependent on sectors and activities [2]. Existing solid waste expenditure levels increased in Malaysia in line with the pattern of economic standard of living and consumption rate [3]. There are many types of solid waste where paper and cardboard form the second biggest component of domestic waste after organic waste, and contribute about $13 \%$ of the total domestic solid waste. Besides, glass accounts for $2.5 \%$ by weight of the total solid waste generated. Meanwhile with

Manuscript History:

Received 20 August, 2014, Revised 29 September, 2014, Accepted 30 September, 2014, Published 30 September, 2014

e-ISSN 2289-7771

Copyright $(2014$ JASPE 
an average $8 \%$ by weight of the total amount of domestic waste, plastic is one of the major constituents in waste stream [4]. Others common type of solid waste that can be found is metal. There are two types of metal, ferrous metal such as iron and steel, and non-ferrous metal such as aluminium, copper, zinc, lead and silver. On an average, metals account for $2 \%$ of total solid waste generated [4].

UNIMAS has the latitude of 1.468793 and the longitude of 110.438288. As of September 2013, the total enrolment of UNIMAS is 16,085 consisting of 14,033 undergraduates, 1,343 postgraduates and 709 pre-university students [5]. In addition, a total of 2,189 staff has been employed as of August 2013 [6]. However, there are no statistics on the waste generation on this population available for the development of sustainable solid waste recovery system. The scopes of this study were the Student Residential College in UNIMAS West Campus, which comprises of five: Tun Ahmad Zaidi (TAZ) College, Bunga Raya College (BRC), Cempaka College, Sakura College and Allamanda College. This is because the population in UNIMAS is concentrated in the residential college during day and night.

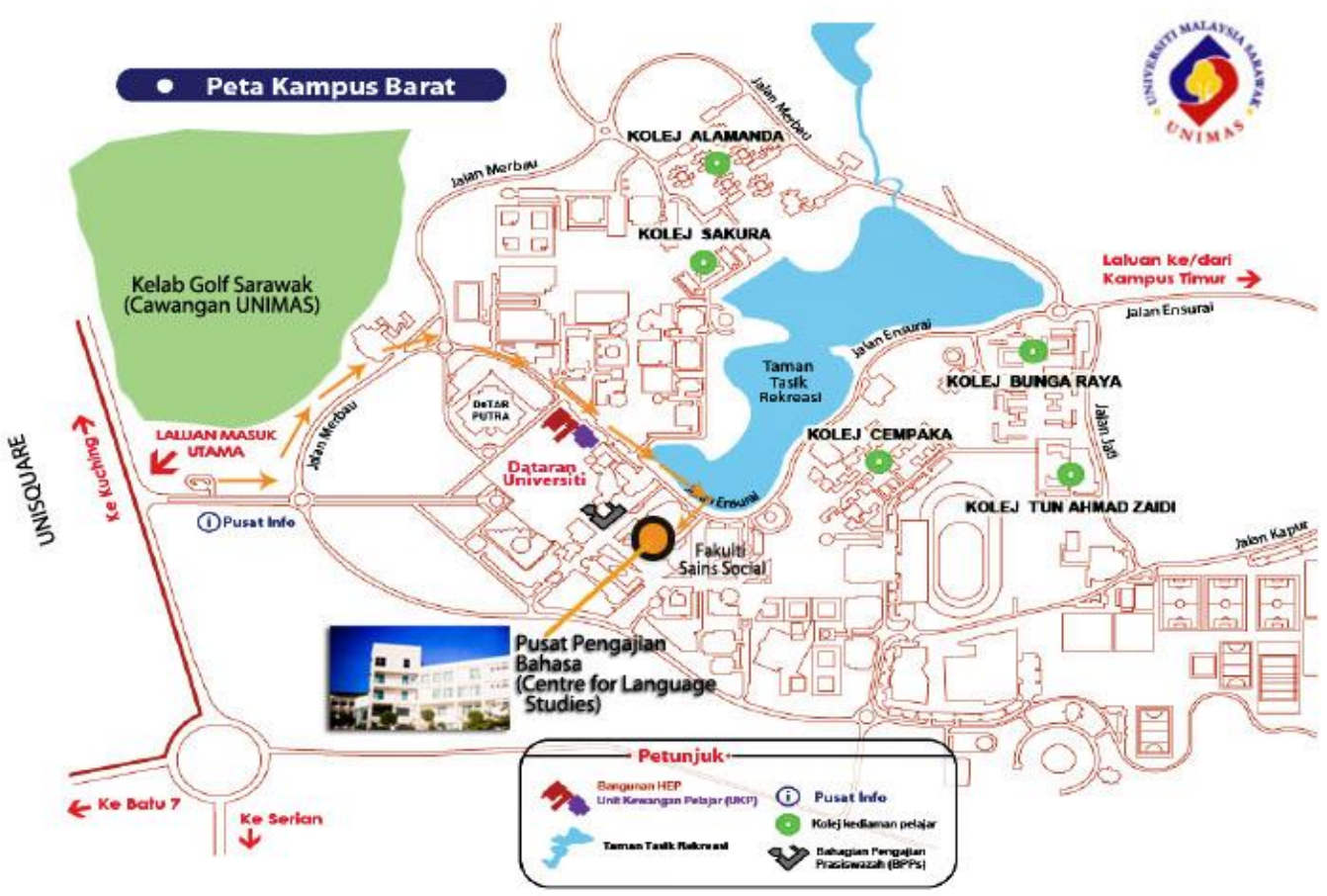

Figure 1: UNIMAS aerial view [1].

\section{Methodology}

This study was conducted within the Residential College UNIMAS west campus compound area. Focusing on the type and amount of wastage produced, data were gained through sampling method. Spot sampling method in this study was according to the Mexican Standard NMX-AA-0151985 [7]. For this study, three days were randomly picked from a week. During each of the day, a sample of black garbage plastic bags was collected from each college: Tun Ahmad Zaidi (TAZ), Bunga Raya College (BRC), Cempaka, Sakura and Allamanda. Then, the samples were weighed according to their respective types. The percentage of each waste type was calculated with respect to total waste generated. Observation on the type and size of all collected waste within the collection area was also one of the methods used. The data collected from waste samples collections were 
analyzed using statistical approach to obtain the mean of percentage or the average of the waste amount according to their composition. This information was used to represent and give an insight of type of wastes and its proportion generated by UNIMAS residents. Besides, it led to the discovery of the approximate amount of recyclable materials in UNIMAS.

\subsection{Energy Content}

The energy content for each types of waste can be calculated by using equations (1) and the theoretical values as shown in Table 1, while the total energy can be determined by using equations (2).

$$
\begin{aligned}
& \text { Energy }(k J)=\text { Energy Content }(k J / k g) \times \text { weight percent }(k g) \\
& \text { Total Energy content }(k J / k g)=\sum \text { Energy }(k J) / \text { Total weight }(\mathrm{kg})
\end{aligned}
$$

Table 1: Energy list according to waste component [8]

\begin{tabular}{|c|c|}
\hline Component & Energy Content kJ/kg \\
\hline Plastic & 326.0 \\
Paper & 167.5 \\
Food waste & 46.5 \\
Tin cans & 7.0 \\
Glass & 0 \\
\hline
\end{tabular}

\section{Results and Discussions}

For each residential college, for three different days a sample of black plastic garbage bags was taken for analysis of waste composition generated. An average was calculated for weekly information. For four weeks of data collection, an average was calculated to gain waste generation in a month. The average waste generation for each residential college based on the sample of three black plastic garbage bags in a week is shown in Table 2.

Table 2: Average weekly waste generation for each college

\begin{tabular}{|l|c|c|c|c|c|}
\hline College & Week 1 & Week 2 & Week 3 & Week 4 & Average (kg) \\
\hline TAZ & 5.5 & 6.2 & 4.9 & 4.2 & 5.2 \\
BRC & 6.9 & 5.5 & 6.2 & 6.6 & 6.3 \\
Cempaka & 6.5 & 5.4 & 5.6 & 5.7 & 5.8 \\
Sakura & 8.0 & 7.2 & 7.7 & 7.5 & 7.6 \\
Allamanda & 8.2 & 8.4 & 7.6 & 7.8 & 8.0 \\
\hline \multicolumn{7}{|l}{ Total } & \multicolumn{4}{|l}{} \\
\hline
\end{tabular}

The tabulated data in Table 2 shows that the highest waste generated in residential college is Allamanda College with average of $8.0 \mathrm{~kg}$ followed by Sakura College, Bunga Raya College, Cempaka College and the lowest is Tun Ahmad Zaidi College. This was probably due to the different in life style of the Allamanda residents where it is the only college that has both international and local students. 


\subsection{Solid Waste Generation by Types}

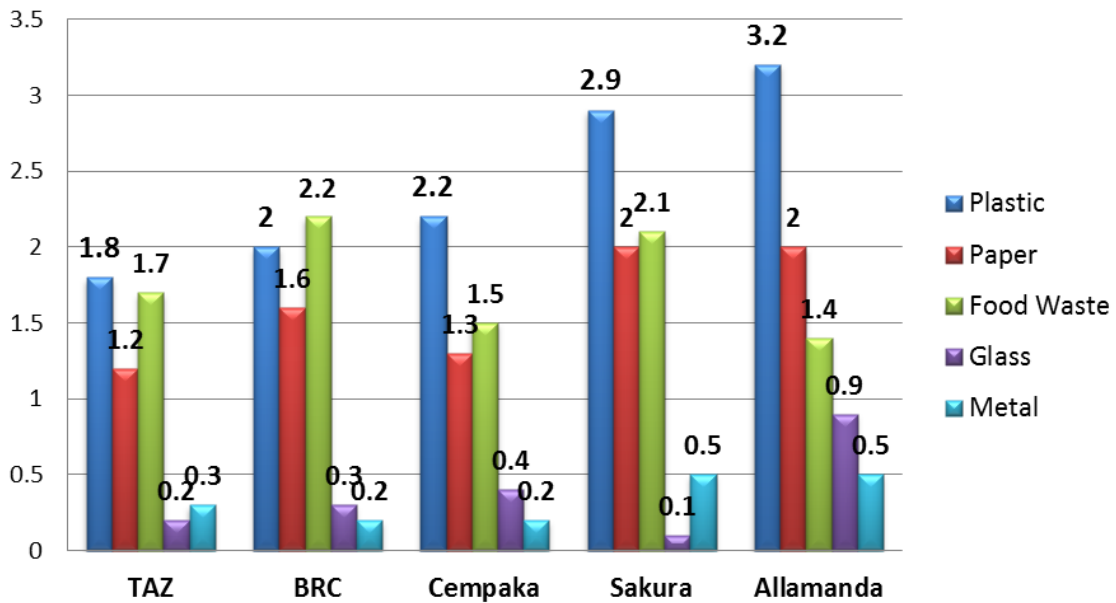

Figure 2: Waste generation by types for all colleges.

Figure 2 shows the waste generation comparison according to waste types between each college. Allamanda College produced the highest amount of plastics with $3.2 \mathrm{~kg}$ followed by Sakura College, Cempaka College, Bunga Raya College and Tun Ahmad Zaidi College. This is due to the fact that most of the household necessities are made from plastic. The lowest waste generated was glass with the amount of $0.1 \mathrm{~kg}$ for Sakura College, while Allamanda College carried the highest amount of glass with $0.9 \mathrm{~kg}$. For recyclable materials, plastics were the most disposed material with an average of 2.42 $\mathrm{kg}$ followed by paper $(1.62 \mathrm{~kg})$, glass $(0.38 \mathrm{~kg})$ and metal $(0.34 \mathrm{~kg})$. This shows that most of the residents used plastic as domestic usage such as carry bags, shower foam bottles, drinking bottles among many others.

\subsection{Total Energy Content}

By referring to Table 1, the total energy content was calculated according to waste components or also known as waste type. The average weight and total energy of each college were calculated to gain the total potential energy of solid waste.

Table 3: Total energy content for each college

\begin{tabular}{|c|c|c|c|}
\hline College & Energy (kJ) & Actual weight $(\mathbf{k g})$ & Energy Content $(\mathbf{k J} / \mathbf{k g})$ \\
\hline TAZ & 16513.0 & 5.2 & 3175.58 \\
BRC & 16268.0 & 6.3 & 2582.22 \\
Cempaka & 18288.0 & 5.8 & 3153.10 \\
Sakura & 18094.0 & 7.6 & 2380.79 \\
Allamanda & 21884.0 & 8.0 & 2735.50 \\
\hline \multicolumn{2}{|c|}{ Total } & \multicolumn{2}{|c|}{14027.19} \\
\hline
\end{tabular}




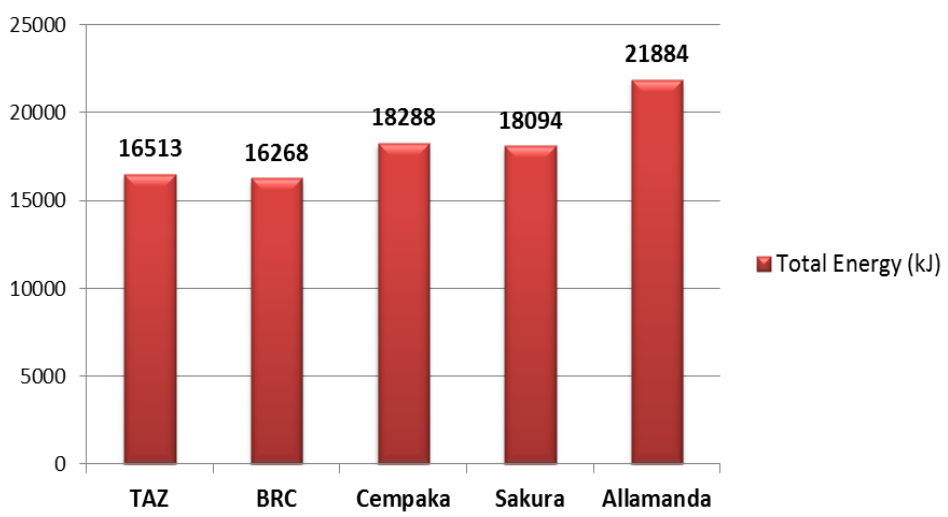

Figure 3: Total energy wasted from each college $(\mathrm{kJ})$.

Figure 3 shows Allamanda has the highest value of energy with 21,884 kJ from waste generation and it is proportional to the weight of waste generated. Therefore, this college has the highest potential for in-situ energy generation or the centralized energy recovery from solid waste can be located at Allamanda College.

Table 3: Total energy content for each college

\begin{tabular}{|c|c|c|c|}
\hline College & Energy (kJ) & Actual weight (kg) & Energy Content (kJ/kg) \\
\hline TAZ & 16513.0 & 5.2 & 3175.58 \\
BRC & 16268.0 & 6.3 & 2582.22 \\
Cempaka & 18288.0 & 5.8 & 3153.10 \\
Sakura & 18094.0 & 7.6 & 2380.79 \\
Allamanda & 21884.0 & 8.0 & 2735.50 \\
\hline \multicolumn{2}{|c|}{ Total } & 14027.19 \\
\hline
\end{tabular}

Meanwhile, Table 3 shows the conversion from average weight of solid waste to energy content. It can be seen that the energy content that was wasted by Tun Ahmad Zaidi (TAZ) College is the highest, which is $3,175.58 \mathrm{~kJ} / \mathrm{kg}$, followed by Cempaka College $(3,153.10 \mathrm{~kJ} / \mathrm{kg})$, Allamanda College $(2,735.50 \mathrm{~kJ} / \mathrm{kg})$, Bunga Raya College $(2,582.22 \mathrm{~kJ} / \mathrm{kg})$ and lastly by Sakura College with $2,380.79 \mathrm{~kJ} / \mathrm{kg}$. The total energy content from these five colleges with their samples of weight range is $14027.19 \mathrm{~kJ} / \mathrm{kg}$.

\section{Conclusions}

From the results, conclusion can be made that the most solid waste disposed by the residents were plastic $(2.42 \mathrm{~kg})$ followed by paper $(1.62 \mathrm{~kg})$, glass $(0.38 \mathrm{~kg})$ and metal $(0.34 \mathrm{~kg})$. The total energy for all components of solid wastes have also been calculated except for glass due to value of energy is zero. Therefore the highest total energy was from Allamanda College with energy of 21884 $\mathrm{kJ}$.

Overall, from this study of solid waste from residential college in UNIMAS West Campus, the total energy content for all colleges was $14027.19 \mathrm{~kJ} / \mathrm{kg}$. For further improvement, this data can be used to study the best way of implementation of the solid waste recovery system and creating potential renewable energy in UNIMAS. 


\section{Acknowledgements}

The authors express gratitude to Universiti Malaysia Sarawak for providing the opportunity and supports to conduct this research.

\section{References}

[1] UNIMAS Official Portal, Contemporary and Forward Looking: <http://www.unimas.my/index.php/en/headlines/100041-unimas-registers-highest-intake-of-students-sinceinception>. Accessed on 15 August 2014.

[2] Tchobanoglous, G., Eliassen, R., \& Theisen, H. (1977). Solid wastes: engineering principles and management issues. McGraw-Hill, New York.

[3] Iwan Budhiarta, Chamhuri Siwar, Hassan Basri (2012). Current Status of Municipal Solid Waste Generation in Malaysia. International Journal on Advanced Science Engineering Information Technology, Vol. 2, No 2 .

[4] Hopkins, E. M., \& Urban Management Program. (1994). The life cycle of urban innovations. UNCHS (Habitat)/The World Bank/UNDP, Washington D.C.

[5] Syed AlMunir M.Zarak and Adam, J. H (2009). Study on Generation and Composition of Solid Waste Produced in UNIMAS Cafeterias, UNIMAS E-Journal of Civil Engineering, Vol. 1, No. 1.

[6] UNIMAS Official Portal, Contemporary and Forward Looking: <http://www.unimas.my/en/about-unimas11267/background.html>. Accessed on 12 August 2014.

[7] SECOFI (1985). Physical, Chemical and Biological Properties of MSW, Educational Slides: http://mebig.marmara.edu.tr/Enve330/Chapter4.pdf, Official Mexican Standard approved by the Committee of Environmental Protection, Mexico.

[8] Takele Tadesse (2004). Solid wastes: engineering principles and management issues. McGraw-Hill, New York.

\section{Authors}

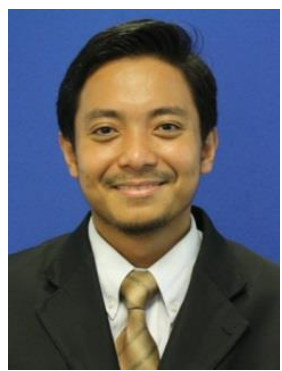

\section{Mohd Azrin Mohd Said}

Mohd Azrin Mohd Said is a lecturer, attached to the Department of Mechanical and Manufacturing Engineering, Faculty of Engineering, Universiti Malaysia Sarawak (UNIMAS). He received his MSc (Manufacturing System Engineering) in 2012. His field of interest is Manufacturing Simulation Modelling, Renewable Energy, Industrial Ergonomic and Human Factor.

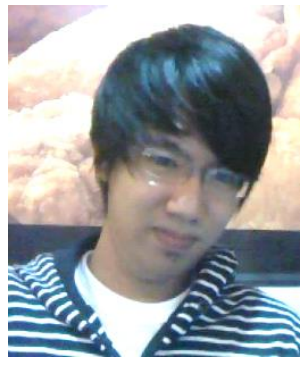

\section{Bush Engat Ritchie}

Bush Engat Ritchie is a student, attached to the Department of Mechanical and Manufacturing Engineering, Faculty of Engineering, Universiti Malaysia Sarawak (UNIMAS). He received his BEng (Hons) Mechanical and Manufacturing Engineering in 2013. 